\title{
戸建住宅における様式・材料の普及構造論の展開 \\ MECHANISM ON THE SPREADING OF STYLES AND MATERIALS OF DETACHED HOUSES IN JAPAN
}

\author{
谷口尚 弘*, 大垣直明** \\ Naohiro TANIGUCHI and Naoaki OHGAKI
}

\begin{abstract}
The purpose of this study is to take the viewpoints of other writers into consideration and establish the new viewpoint about the mechanism of the spreading styles and materials of the detached houses in Japan. The results are followings.

1) The spreading of the styles and materials is process of communication.

2) The spreading is influenced by the climate and traditional characteristics of the region.

3) The regions have the filter-system judging whether the new styles and materials agree their climate and traditional characteristics or not.

4) The concept of spreading contains the regional differences.
\end{abstract}

Keyword : housing, regional differences, spreading, communication 住宅生産・供給, 地域性，普及，コミュニケーション

1.はじめに

\section{1 研究の背景}

高度経済成長期における技術開発の進歩によって，新しい住宅様 式・材料（近代的様式・材料 ${ }^{1}{ }^{1}$ ) 加開発され，住宅不足や需要の 多様化に対応した。それは利便性・機能性・合理性といった近代化 を指向するものであった。その結果, 従来の地域固有の住宅様式・ 材料（以後，様式・材料）は浸食され，全国各地の户建住宅供給は 「画一化」・「普遍化」の方向に進行し，地域固有性いわゆる地域 性が崩壊しつつある。それに加え, 住生活・地域経済・室内環境の 面等にも新たな問題を引き起こしている22。

ものの「画一化」・「普遍化」に至るまでの過程は普及現象の結 果生じるものであり, 社会的現象之捉えられる。住宅も社会を構成 する要素, 社会的価值財産 ${ }^{3)}$ と位置づけるならば, 当然, 普及現 象が生じる。しかし住宅は他の商品にない長期耐久性・土地固着性 といった特質を有しているため, 他の商品とは異なる普及現象であ ると考えられる。

その普及現象の結果によって生じる「画一化」・「普遍化」は， 一般的・共通的という面においては同義であるが，普及現象・普及 過程を捉える場合，異なる意味をもつと位置つけ，それぞれの一般 的な意味，普及を踏まえた意味を以下のように捉えた。
まず，一般的な意味は4，

i ）「画一化」は，個々の性質や事情は重視せず全体を一様にそろ えること，型にはまっているありさま，

ii）「普遍化」は, すべてのものに共通に存すること, すべてのも のに通ずる性質,

であり，普及を踏まえた場合の意味は，

i ）「画一化」は，そのものを対象の意志に関わらす強制的に普及 させること，様式・材料でいえば，その地域的条件を無視し全 国同じ様式・材料をく採用しなければならない〉という強制 的・義務的展開による現象であり，

ii）「普遍化」は，異なる地域であってもそのものに対して共通の 意識・認識を有していること，また「画一化」を普及の強制 的・義務的展開と捉えると「普遍化」は合意的展開による現象 である。

つまり，普及現象の結果，一様に全国で採用したとしても，「画 一化」に至るまでの過程（「画一的」普及過程）と「普遍化」に 至るまでの過程（「普遍的」普及過程）の二つの過程が存在して

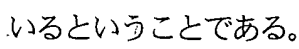




\section{2 既往の普及・地域性研究とその関わり}

筆者の普及現象の研究は，建築学とりわけ住宅生産・供給分野に おいて検討しているものである。しかし，普及現象の研究対象は社 会学や経済学などで取り上げられ，そこで普及現象もしくは普及の 概念を定義している場合が多い。E.M.Rogers による普及過程の定 義をみると『ある社会システムの成員の間を，なんらかの「コミュ ニケーション・チャンネル」を通して, 時間䡛に沿って「イノベー ション」が伝達される過程』5), 田中においては『新しいアイ ディアとしての「イノベーション」の存在を知ってから, それを採 用することを決定するまでのあいだに行う「コミュニケーション」 行動』 6) としている。また, 建築学において先の E.M.Rogers の普 及論を用いて巽らは『社会成員の構成員の間に「イノベーション」 という特定のメッセージが泓がるプロセスであり，「コミュニケー ション」の1つのタイプである。・普及は「コミュニケーショ ン」機構を通じて行われるから, 社会の情報が進んでいれい゙いる程, 普及は迅速で確実に達成されるし，・・』7)と述べており，こ れらの論述から普及現象は「コミュニケーション」現象，すなわち 情報伝達過程と位置づけられよう。

一方, 古川の地域性論において 他の地域との差異性は流動に よってあらためて確認される』 ${ }^{8)}$, 古田は文化変容論を念頭にお いて.『ある社会に新しい技術䔟転されて, 関連するいくつかの文 化要素との間で引き起こす摩摖や矛盾の発現形態や，その処理のし かたのなかに, 受け手の社会の関与を読みとることが可能』 ${ }^{9)}$ と 述べている。流動=くものか慟く〉ことをくものが動く〉過程=普 及と捉えるならば，他地域力らのものの普及 (流動)によってその ものの性格を再認識 (善し悪しは別として) できると位置づけられ る。さらに古田は地域間の相互作用から『土着の諸变数は確かに地 域の適応パターンを左右するが，地域間のインター・アクションも また，適応パターンに影響を与える』と述べており，普及によって 生じるものの変動・変化は，地域と地域の間で起こりうる現象であ り，その普及過程を明らかにすることによって「画一的」過程か 「普遍的」過程かを明らかにすることができることを示唆している といえよう。

ところで，いままでの多くの住宅生産・供給研究は，各地域の住 宅を事例対象として住宅の地域的特徵を明らかにし，地域を主体と した住宅のあり方, 地域条件を内包した住宅生産システムの提案を 行っている ${ }^{10}$ 。これらの研究は地域性すなわち地域固有性が重要 であることを指摘しており, 各地域における事例研究は他の地域住 宅研究および住宅生産・供給研究に対して多くの示唆やヒントを与 えるという意味において大きな意義をもっている。

これらのことから普及研究と地域性研究の両者を踏まえ, 住宅生 産・供給問題研究を行う必要があると位置づけられる。

\section{3 普及研究の位置つけけ・視点と研究の目的}

筆者は近年における様式・材料の「画一化」・「普遍化」の現象 に着目し，それを引き起こしている普及現象，すなわち新しい様 式・材料が採用され普及していく過程，逆にいえば従来の様式・材 料が浸食されていく過程の分析を通して, 地域条件を尊重した新し い住宅生産・供給のあり方，地域性を考慮した住宅のあり方（様 式・材料の選択・採用）を再構策しなければならないと位置づけ研

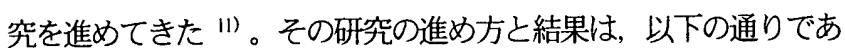

る。

1つはマクロな視点，すなわち近年の様式・材料の採用状况を都 道府県単位て整理し，その地理的関係加「画一的」過程か「普遍 的」過程かを捉えようとする視点である。いわば普及の状況を鳥玫 的に捉えながら様式・材料ごとの採用・普及の特性，普及圈域の形 成，さらにそれらを異なる時点で比較（圈域形成のプロセス）を分 析した。その結果,

i）様式・材料には「画一化」・「普遍化」しやすいものと，「画 一化」「普遍化」しずらいものがあること，

ii）新しい様式・材料には普及の起点があり, そこから地理的に連 続しながら圈域を形成する。その圈域形成の要因には, 都市化 要因, 気㬋対応要因 (北方性および南方性), さらに生産基盤 要因（生産技術性および生産伝統技術性）があり, それらは単 独で成立している場合と併存している場合があること，

iii）様式・材料の普及には時間差があること。また，ある一部のみ で常に高い採用状況を示している様式・材料があること，

などの知見が得られ，近年における生活習慣の近代化や住宅生産・ 供給のネットワーク化にも関わらず, 様式・材料の大半はその地域 と深く結びついていること, つまり「普遍的」過程で普及が進行し ていることを明らかにしている。

2つはミクロな視点，すなわち様式・材料の意志決定過程に着目 し, 普及の内部構造（強制的展開か合意的展開か）をみようとする 視点であり, 具体的には意志決定と地域的要因および個別的要因の 関わりを分析した。その結果,

i）居住者の意志を介さないて採用（決定）される法律・制度, 技 術・手法は, 最も強い強制的要因で普及に影響を与え「画一 的」過程と位置づけられ, また生活慣習・伝統性も地域的要因 として普及に強い影響を与えており，「普遍的」過程と位置づ けられること，

ii）個別的要因は，居住経験，住宅観，生活スタイル，家族属性な ぞがあり意志決定に作用するが，とりわけ居住者の住宅観は都 市化の進行がはやい地域のほうが意志決定に強い影響を与えて いること,

などの知見が得られ，普及現象は意志決定に関わらず強制的展開で 進行する場合之, 居住者・地域の意志決定と関わって進行する場合 (合意的展開) があるが，それぞれ地域差が生じていることを明ら かにしている。

本論は，筆者がいままで明らかにしている一連の普及研究を通し て，巽や田中らの普及論および古川や古田らの地域性論の検証ある いは補足・再整理を試みることを目的としている。

\section{2. 普及論の展開}

\section{1 普及およひ圈域の概念検討}

まず，普及の具体的概念検討を試みる。採用は一般的に単にもの をく用いる〉ことであり，1対1の生産単位で発生する現象である。 それに対し普及は一般的にく広くゆきわたる〉こと，領域（地域ま たは圏域）と時間のなかでものがく広がっていく>現象であり， 個々の採用の集積の結果が普及ということである。たとえば，それ ぞれの個人がものを選択する現象が採用（決定）であり，それが他 の領域・圈域て採用されく広がっていく〉現象が普及ということに 
なる。つまり普及はく広がっていく〉現象， すなわちある起点（ものが最初に開発される地 域・場所）から，外に同心円状に向かう流れで あり,「水の波紋 と類似の現象であろう（図 一左）。しかし, 様式・材料の場合は「水の波 紋 のく広がりかた>とは異なり, 同心円状に 均質にく広がる〉のではなく, 歪な形をとると 考えられる。（図一1，右）。それは様式・材 料の普及には，地域固有性（地域性）が介在し ているためであり，その地域固有性を尊重しな がらく広がっていく>場合（「普遍的」過程）之地域固有性を介 さないで強制的にく広がっていく〉場合（「画一的」過程）があ ると考えられる。

いまひとつ捉えておきたいのは，地域と圈域の相違である。両者 は空間を構成している領域」という面においては同義であるが, その領域の形成過程が異なるため別の意味をもつ。地域を「気候・ 風土がほぼ近似した空間領域であり, 空間の特性に関わる何らかの 事象に対して共通性をもった領域」と捉えるならば，普及は「地域 を越えてく広がっていく〉現象」であるため，圈域は「地域を越え て形成される領域」と捉えることができ，共通性をもたなくても圈 域という領域は形成される。すなわち圈域は普及現象によって生じ る領域であるということであり，圈域はく大きさが異なる〉<重複 する>こともありえ，あるものの性格や環境要因によって多様な領 域が成立すると位置づけられる。

\section{2.イノベーションの発生過程と普及現象}

普及現象の一つにイイノベーション」すなわち受容主体が新しい と知覚するもの, いわゆる技術開発・技術革新であるが, 普及の前 段階である採用の時点において重要なキ一となる。つまり「イノ ベーション」がなければ採用はあり得なく，採用がなければ「画一 化」 :「普遍化」もあり得ない。また「イノベーション」の内容に よって普及現象は異なる。たとえば，その「イノベーション」が強 い力を有していれば普及に強い影響力を与え，〈広がりかた >がく 早くなったり〉く大きくなったり〉し，「イノベーション」の強弱 が普及促進の一要因となる。さらに「イノベーション」はくどこの 地域で展開するか〉によって普及現象が異なる。

筆者の研究において「イノベーション」発生地域を普及の起点と して捉え, 新しい様式・材料における普及の起点とそこから地理的 に連続して形成されている圈域，さらに「イノ゙ーション」発生内 容について明らかにしている。具体的には，

i ）新しい様式・材料の普及は地理的に連続して一定の圏域を形成 しているが, その圏域形成の要因には東京や大阪といった大都 市圈を起点とした都市性, 北海道や九州地方に起点が存在する 気候対応性（北方性および南方性），さらにプレハブ住宅の建 設の状況や伝統的工法の継承の状况之関わっている生産基盤性 があること,

ii）それらは単独で成立している場合とユニットバスのように北方 性と生産基盤性（滋賀を中心としたプレハブ住宅多供給地域）

や, サイディングのように北方性と伝統的生産基盤性（九州地

方）による圏域が形成され併存している場合があること,

である。新しいものの「イノベーション」は新しい技術・開発能力
理論的〈広がりかた〉》。

《現実的〈広がりかた>》

図一 $1<$ 広がりかた>の模式図

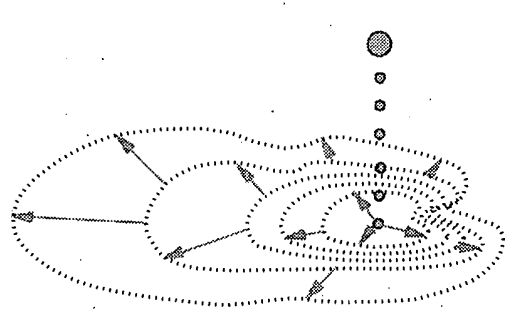

を有する地域で存在し，そこから「水の波紋」のように普及するの が一般的である。筆者の現時点における研究結果においては, 様 式・材料の普及には4つのタイプ (都市性, 北方性, 南方性, 生産 基盤性)の「イノベーション」の存在が読みとれ，都市性に加え他 の要因，すなわち北方性・南方性・生産基盤性といつた $3 つ$ 要因 で「イベーション」が生じていることが一つの特徴である。都市 性以外の他の3つのタイプによって普及現象が生じている様式・材 料は, 地域色か強い様式・材料であるといえよう。これらの3つの 要因による普及は, 単一として圈域が存在している場合が多いが,

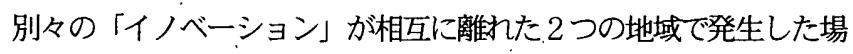
合には，両地域から普及現象が生じていることが読みとれる。たと えば，ユニットバスにおいては北海道の気候条件に対応するために 開発・普及され，今日では北方地域で「普遍化」を獲得している。 一方, それが工業化製品としての性能が評価され，プレハブ住宅と のワンセット供給が可能であることが，「イノベーション」可能な 地域（プレハブ住宅建設地）とりわけ滋賀を中心に普及したと捉え られる。このように普及を情報伝達過程と捉えた場合, 「イノベー ション」が地理的に連続していないところで発生し, 別の普及圈域 を形成することも一つの特徴である。

\section{3 情報伝達による普及への影響}

先にも述べたが，普及現象は「コミュニケーション」現象，すな わち情報伝達過程である。その情報伝達（コミュニケーション・ チャンネル）をくどこに向けるのか〉く送るのか，さらにくどの ように受けとるのか>が問題となる。先の巽らの論文のなかで普及 のメカニズムを『その対象が客観的に新しいかどうかが問題ではな く, たとえ他では在来のものであっても，コミュニケートされるメ ンバーにとって, 新しいと知覚される場合・・・, 新しいという ギャップが生じる時に普及のメカニズムが働く』と述べており，近 年の「イノベーション」進行時代のなかで, 受容に介在する現象が 重要であると理解でき, その受容主体は居住者（個別）であったり 地域であったりする。

最もミクロな受容主体はその地域に属する居住者である。たとえ ば, 居住者が新しいもののほうに「チャンネル」をく向けたり〉く 受けとったり>すると新しいものが普及する。しかし，何故その新 しいもののほうに「チャンネル」をく向けたのか〉く向けなければ ならないのか〉が問題であろう。現在, 住宅を取得する場合, ホー ムセンター, 新聞広告, 雑誌など, 居住者にとって多くの「コミュ ニケーション・チャンネル」が用意されているため, <受けとりか た〉は普及現象を大きく左右する。新しい様式・材料に対する情報 は都市規模が大きいほど多く, 普及に大きな影響を与えている。逆 
に都市規模が小さい都市においては情報の少なさに加えて「伝統保 持力」. ${ }^{12)}$ がはたらき，新しい様式・材料の採用を否定し，従来の 様式・材料を継承している傾向がみられる。居住者は自らの住宅観 に加え，他人からの情報や住宅建設時における地域大工・工務店か らの情報が意志決定の主要な拠り所となっている。それは大工・工 務店は地域条件に対応した住宅建設の担い手であると同時に, 新し い情報がその地域にく適合するかどうか〉の判断能力を有するため である。このように都市規模によって情報伝達過程が異なり, 都市 化の状況が普及現象を左右する一方で, 居住者および大工・工務店 の住宅観も普及現象を大きく左右するといえる。しかし，それらの 受容主体か新しい情報をく受けとったのか（新しい様式・材料をそ の地域で必要と判断したのか：合意的展開）>く受けとらなければ ならなかったのか（新しい様式・材料を無理矢理, 採用しなければ ならなかつたのか : 強制的展開) >が，近年の普及現象を捉える場 合, 最も問題とすべきところであろう。

\section{4 普及における「地域性の壁」}

普及現象は情報伝達過程であり，そのなかで生じている過程，す なわちその情報伝達によって受容主体がく受容するのか〉く拒絶す るのか>の過程であると理解できる。その法則性や構造を見極める ことが普及構造研究の本質的課題であり, 普及と地域 (地域性) と の関わりについて捉えることが重要である。

古川の地域性論をみると『地域性は支持条件の変化に応じて極め て動的な挙動を示し，地域は孤立閒鎖の性質と連続開放の性質の両 面を有している』と述べており，様式・材料の流動的な圈域性，す なわちある条件に基づいて地域性や普及圏域か形成・変化すること を示唆している。このような流動的な圈域形成は地域間に「地域性 の壁」とでもいえる「フィルター構造」が存在しており, 普及は新 しい様式・材料が入り込もうとする「情報伝達力」と従来の様式・ 材料を継承しようとする「伝統保持力」の拮抗状態によっていると

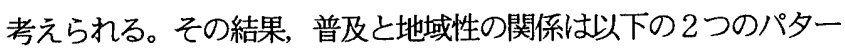
ンがあると捉えられる(図一2)。

i ）周辺の圏域から普及の進入が性能上の優位性や情報の影響など により,「地域性の壁」を突き破って進行し, 新しい様式・材 料が採用されるパターン（連続開放型），

ii）周辺の圈域からの普及の進行が「地域性の壁」によって阻まれ, 従来の様式・材料が継承されるパターン（閉鎖型），
である。普及と地域性の拮抗状況は，様式・材料によって異なって いることは筆者の研究によって明らかにしているが, 新しい様式・ 材料が容易に普及する場合としない場合がある。

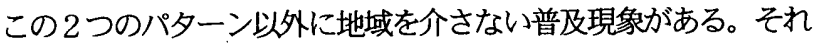
は制度・法律，技術・手法などであり，新しい様式・材料を強制的 に普及させる力を有している。たとえば, 筆者は高断熱・高気密化 の普及過程の分析，すなわち金融公庫融資条件と居住者意志につい て分析しているが，そこで居住者は高断熱・高気密化に対しては高 く評価している一方で, 生活上の必要性から高断熱・高気密化と矛 盾する勝手口や 1 階ベランダなどの保持を強く希望していることを 明らかにしている。融資条件は效率的に高断熱・高気密化を達成し てきているが, 居住者の意志に反して普及している状況があり,

「画一的」過程による普及といえよう。

新しい情報とその量や新しい情報の〈受けとりかた〉も普及を促 進させる要因である。しかし，その情報が伝達されない場合，また 伝達されても「地域性の壁」に阻まれる場合がある。その場合，地 域の「気候条件」や「伝統保持力」が普及を閉ざす要因となってい る。つまり「気候条件」に合致しないものであれば情報が伝達して も普及が進行せず，また「気候条件」に合致しても「伝統保持力」 が強ければ普及しない。このような構造が普及過程に存在し，その 拮抗状態が多様な普及現象を生じさせている（図ー3）。たとえば, 筆者は北海道力ら東北地方とりわけ青森における北海道型様式・材 料の普及現象について分析している。そこで無落雪屋根が青森で高 普及しているのは，多降積雪の問題解決のため伝統保持より積雪寒 冷地仕様を重視した結果であることを明らかにしている。このこと は生活上の必要性によって「伝統保持力」が弱まった結果であり， 居住者がその様式・材料に対し〈合意した〉結果であると捉えられ， 「普遍的」過程による普及といえよう。

また，伝統保持が極めて高い島根県において，新しい様式・材料 之従来の様式・材料の拮抗状態を分析した結果 ${ }^{13)}$, 以下の知見が 得られた（図一 4)。島根県では従来の様式・材料の継承が根強く いが, その背景として,

i）住宅で常会が開かれる風習が，いまだに残っていること,

ii）出身地が島根県の人が大半であり人口移動が少なく，緑もゆか りもない人が住まないという傾向か漒く，県民意識（強い継承 意識) が抵抗力として作用していること,
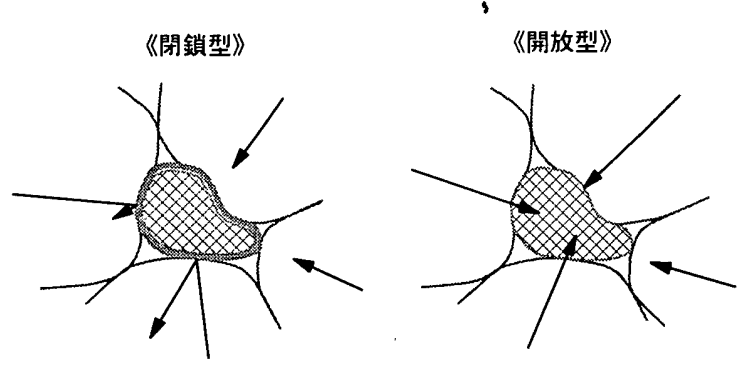

は，従来の住:宅様式・材料を採用してる圈域を示す。

は、新しい住:毟栐式・材料を採朋している图域を示す。

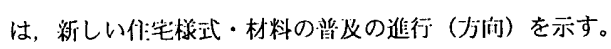

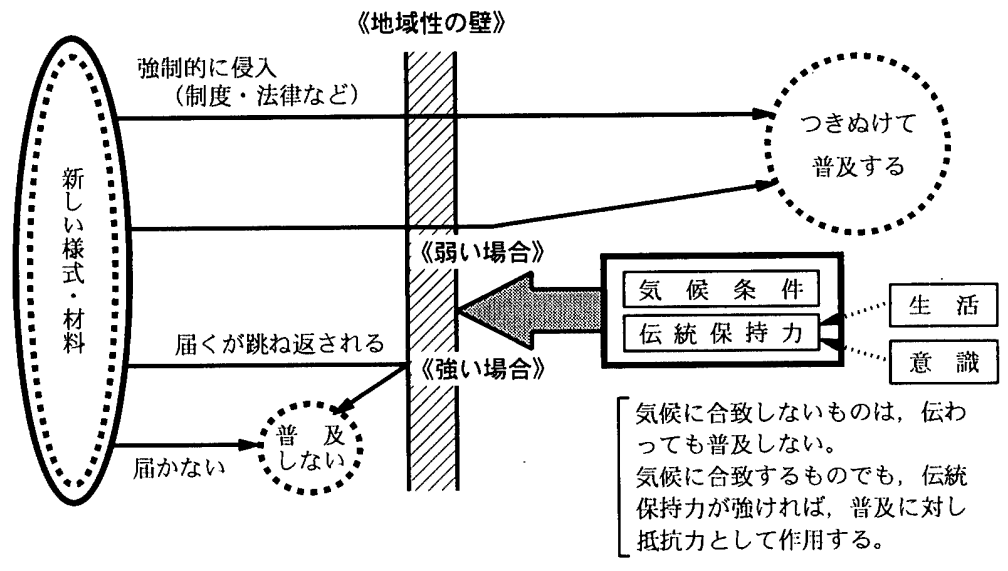

図 - 2 開放型と閉鎖型

図-3 地域性と普及の関係 
iii）残すべき第 1 位の伝統的様式・材料は石州瓦であり, 強い「伝 統保持力」が存在していること,

iv）住宅政策においては「しまねの家 $21 」 の$ 創設や，古い住宅の 記録（痕跡を整理し，残す）として島根県地域建築資料集成を 作成中することによって，伝統性を残そうとしていること， などがあげられる。それに対し, 新しい様式・材料は都市部のしか も一部の様式・材料のみ普及しているが, その背景として,

i ）鉄骨プレハブでは石州瓦は約10\%で彩色石綿板が約 $90 \%$ あり, 新しい供給システムでは様式・材料がワンセットとなって採 用・普及していること,

ii）木造住宅生産合理化システム認定や情報開示, OA機器の貸し 出しといったように, 生産システムの近代化が関与しているこ と,

などがあげられる。このように島根県では新しい様式・材料が従来 の様式・材料を容易に浸食できず, 従来の様式・材料の優位性を尊 重し, 地域に合致しない様式・材料を否定する強い「地域性の壁」 が存在している。

普及現象のうち，いまひとつ捉えておかなければいけないのは, 時間経過のファクターの存在である。筆者の時間経過（圈域形成の プロセス）分析の結果, 各様式・材料には時間的差異が生じている ことを明らかにしている。それは「地域性の壁」が存在しているた めであり, 地域間で拮抗状態が生じている場合は普及するのに長時 間を要するし，それがない場合には短時間で普及する。つまり「地 域性の壁」がなければ一気にかつ全域にく広がっていく〉が，「地 域性の壁」が存在する場合にはその強弱によって要する時間も広が る空間にも差異が生じる。このことは，地域間の拮抗状態は合意的 展開のなかで生じる現象であることを示している。

この時間経過を踏まえるうえで考虑しておかなければいけないの は, 短時間の普及現象いわゆる流行的現象である。流行的現象は強 い「情報伝達力」によって一気に普及し，一気に衰退する構造4) を有しており，「地域性の壁」による影響，すなわち地域間の拮抗 状態がない現象である。そのため, 容易に取り替えがきく様式・材 料においては流行的現象はありえようが, 構造体や強い地域性を有 する様式・材料においては流行的現象は起こってはならないと考え る。近年, 住宅寿命の長期化 (高耐久化) が重要な課題とされてい るが，流行的現象はますます大きな問題となろう。

\section{3. おわりに}

本論文は，筆者がいままで明らかにしている一連の普及研究を通 して，他者の普及論・地域性論の検証あるいは補足・再整理を試夕 た ${ }^{14)}$ 。その概要は, 以下の通りである。

i ）近年における住宅生産・供給において重要視すべきことは, ‘゙ のように地域性を捉えながら普及現象を捉えるかである。つま り普及之地域性を個別的・相反する概念と捉えるのではなく, 地域性の存在を普及の一現象, 普及現象は地域性を内包する概 念と捉えなければならない。逆にいうならば, 地域性の存在は 普及現象の結果生じるものと位置づける必要がある。普及現象 を地域性を内包する概念として捉えることにより，地域性㱔失 も理解できると考えられる。

ii）普及過程には強制力による「画一的」過程と受容主体の合意に

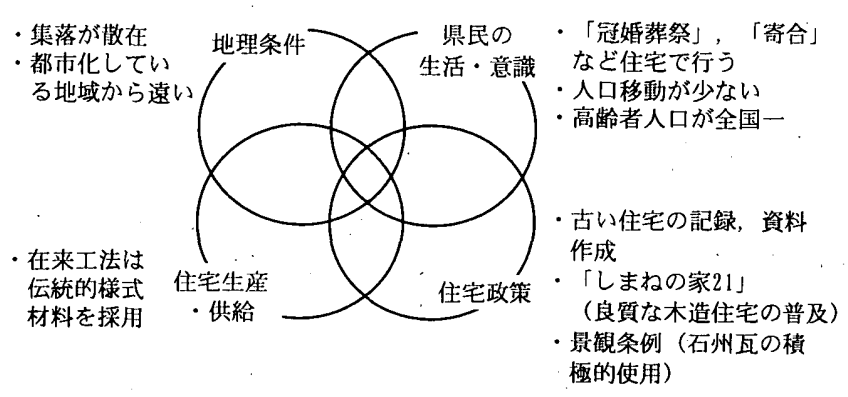

図一 4 島根県における伝統保持の構図

基づく「普遍的」過程がある。前者は法律・制度といつた強制 力によって新しい様式・材料の普及が進行する過程であり，そ の普及過程は合理性を有している側面もあるが，一方で地域の 条件や居住者の意志・意識に反する側面を有している。後者は 地域間に存在する「地域性の壁」の介在によって，新しい様 式・材料をく受容したり〉<拒絶したり〉する「フィルター」 構造を有している。

iii）近年，融資制度条件や性能表示制度などによって住宅生産・供 給上「画一化 が進行しているが，現実には様式・材料や地域 によって普及現象は異なっている。このことは普及が合意的展 開で進行している結果を意味しており，地域性がいまなお存在 していることを示すものであろう。

これからの課題として, 以下の点を指摘しておきたい。

i ）近年の情報過多の時代にあって，情報の受容者である居住者は その過度な情報に惑さされないことである。住宅は居住者と関 わり相互に影響しあいながら形成されるものであるため, 居住 者の情報選択能力や住宅維持管理能力を向上させる必要がある。 そのためには居住者自身が明確な住宅像と情報に対する的確な 判断能力をもち, 空間づくりや住宅づくりに積極的に関わるこ とが必要である。それにはこども時代から住宅に関わる学習が 必要であり, 衣・食・住のなかで最も遅れているといわれてい る住教育のあり方が問われている。

ii）近年の情報化時代，すなわち情報網が全域に対応する現在にお いて，その地域に適合した住宅情報のチエック機能が用意され る必要がある。今後の住宅生産・供給の方向を見定めたうえで, 正しい情報を伝える手法としくみを用意しておかなければなら ない。

\section{【注釈 】}

1）この一連の研究において高度経済成長期以降に開発・普及している様 式・材料を近代的様式・材料，それ以前に普及していた様式・材料を伝 統的様式・材料と位置づけている。

2）たとえば, 鈴木は『住宅の閉鎖化によって近隣や社会に対する連帯感が 失われ人間関倸が希薄化すること』，坊垣も『他者と触れあって支えな がら住宅がつくられるべきである』と指摘し，また秋山および古川は 『住宅活動は社会経済に影響を与える』，とりわけ古川は『地元資源の 利用は地元産業の需要を増し, 所得・雇用の機会を地元にもたらす』と 述べている。参考・引用文献 1) 参照

3）巽らは『住宅は社会性をもった財，すなわち住宅は生活の基盤であると 同時に都市を形づくる基本的な要素で, 住宅のありようは市民の生活は もとより，都市の美観，地域社会の維持形成とも密接に関係している』 と捉え，住宅は社会的価値財産と位置づける必要性を示唆している。参 考・引用文献 2) 参照

4) 広辞苑, 大辞森による

5）E.M.Rogersは伝播分析に欠かせない要素として(1)イノベーション（the 
innovation），(2)ある特定のチャンネル（certain channels），(3)時間経過 (over time），(4)ある社会体系の成員（the members of a social system）を あけてている。参考・引用文献 3 ) 参照

6）参考・引用文献 4）参照

7）参考・引用文献 5）参照

8）古川は住居の地域性を『地域社会の自己表現であり，熟練技能の手と頭 之心は，その自己表現過程の一つである』と捉えている。参考・引用文 献 1) 古川論文参照

9）古田は地域適応の多様性を地域間の相互作用（interrelation）を視野に入 れながら，地域レベルにまでさかのぼり比較検討し，地域適応の多様性 すなわち移転技術に対する適空パターンは著しい地域性を示すこと, ま たあるものの生产地は経済的変動と同時に, 移転技術との接触による土 着と外来との文化的な摩擦やそれに伴ってさまざまに社会的変容か溌生 していることを明らかにしている。参考・引用文献6）参照

10）たとえば，秋山は地域型住宅生産システムを構筑する重要性を指摘し， 地域の准宅生産システムの存在意義について明らかにしている。参考。 引用文献 1）秋山論文参照

11）参考・引用文献 7）参照

12）本論文における「伝統保持力」とは，新しい様式・材料の普及に対して 抵抗する力であり，その地域において㪚から受け継がれてきた生活慣習 や意識と位置つけけている。しかし, 単に昔から存続しているという事実 だけではなく，それに加え，現在およびこれからもく存続させたい〉と いう価值判断を伴う力である。

13）筆者の研究において最も伝統的様式・材料か残存している地域は，島根 県であることを引用・参考文献 7）で明らかにしている。ここでの分析 テー夕は，統計およびヒアリング調査・観察調査の結果であり，ヒアリ ンク調查・観察調查は 1998.9 に島根県建築住宅課および住宅展示場 (松江市) 調査員に実施した。

14）本論文において普及を地域と地域の間で起こる現象と捉えながら論を展 開している。そのため，地域・領域内での普及とりわけ1対 1 （個と 個）での情報伝達過程・対応関倸について分析からはずしているが，そ れについては今後の課題としたい。

\section{【参考・引用文献 】}

1）鈴木成文 : 住まいの計画住まいの文化，彰国社，pp. 224～230，1988.11 坊垣和明: 温暖地における断熱・気密化の効果と課題一住まい方と工ネ ルギ消費に関する全国調査から一, 日本建築学会北海道支部研究報告集 №72, pp. $619 \sim 622,1999.3$

秋山哲一: 地域型木造住宅生産システムに関する研究, 京都大学学位論 文, pp. 3 39，1990 古川修: 木造住宅の生産組織，住宅建築研究所報 第 10 号, pp. 25〜 48, 1984.3

2）「住宅は社会性をもつた財」研究会：「住宅は社会性をもつた財」研究 報告書，(社) 住宅生産団体連合会（座長：巽和夫），1997.4

3) E.M.Rogers and F.F.Shoemaker : Communication of Innovations（宇野善康訳 「普及学入門」，産業能率大学出版部, 1981)

4）田中伯知：伝播分析（コミュニケーションと情報），芦書房，pp.91〜 $95,1996.5$

5）巽和夫ほか : 住宅計画・生産・供給における技術・手法の地域圈への普 及過程に関する研究，昭和 62 年度科学研究費補助金 $\mathrm{A}$ 研究成果報告書, pp. $1 \sim 58, \quad 1993.3$

6）古田和子：製糸技術の移転之社会構造（生活の技術 生産の技術），岩 波書店, pp. 193 213，1990.2

7）大垣直明, 谷口尚弘: 新築戸建住宅における住宅様式・材料の普及構造 に関する研究，日本雪工学会誌 Vol.13 No.3，pp. 16〜23，1997.7 谷口尚弘，大垣直明 : 新筑戸建住宅における様式・材料の普及構造に関 する研究一普及圏域および普及過程の地域性一，日本建築学会計画系論 文集 Na519，pp. 225〜231，1999. 5

谷口尚弘，大垣直明：東北地方にお打る住宅様式・材料普及の地域性に 関する研究，日本建築学会計画系論文集 No.516, pp. 217～222，1999.2

（2000年 7 月 10 日原稿受理， 2001 年 1 月 18 日採用決定） 